\section{Efficacy of Excision, Cauterization, and Fungicides for Management of Apple Anthracnose Canker in Maritime Climate}

\author{
Whitney J. Garton ${ }^{1}$, Mark Mazzola ${ }^{2}$, Nairanjana Dasgupta ${ }^{3}$, \\ Travis R. Alexander ${ }^{1}$, and Carol A. Miles ${ }^{1,4}$
}

AdDitional INDEX wORDs. Bordeaux mixture, copper hydroxide, Malus $\times$ domestica, Neofabraea

SUMmary. This study was designed to determine the efficacy of canker excision (CE) followed by a subsequent application of cauterization (CAU) and/or fungicide treatment to the excised area for the management of anthracnose canker (caused by Neofabraea malicorticis) on cider apple (Malus $\times$ domestica) trees. Three experiments were conducted from 2015 to 2017 , with one experiment each year, in an experimental cider apple orchard in western Washington where trees were naturally infested with $N$. malicorticis. Treatments were applied once in December and data were collected January through March. Treatments in the 2015 experiment were $\mathrm{CE}+\mathrm{CAU}, \mathrm{CE}+\mathrm{CAU}+$ copper hydroxide, $\mathrm{CE}+\mathbf{0 . 5 \%}$ sodium hypochlorite, Bordeaux mixture (BM) only, and CE + copper hydroxide (control). The 2016 experiment included the same treatments as in 2015 plus one additional treatment, $\mathrm{CE}+\mathrm{BM}$. In 2017, one additional treatment was added, CE only, and CAU treatments were removed as they caused significant injury to the trees. Canker size was measured pretreatment, and the treated canker or excised area was measured posttreatment every 2 weeks for 13-15 weeks. Compared with pretreatment, cankers treated with $\mathrm{BM}$ did not increase in size, while the excised area treated with CAU increased 28-fold in size on average, and the excised area treated with $0.5 \%$ sodium hypochlorite or copper hydroxide increased up to 4 -fold in size. Each year new cankers developed in all treatments 13-15 weeks after treatment application, at a time of year when there should not be any spores present to cause new infections. Dark brown streaking, indicative of the disease, was observed in the tissue below the intact or excised cankers $\mathbf{1 5}$ months after treatment application all years. Although $N$. malicorticis was not isolated from symptomatic tissue, symptoms were observed in all treatments including where cankers had not been excised and there was no wounding of the cambium tissue. Findings from this study indicate that of the treatments evaluated, the application of copper hydroxide after $\mathrm{CE}$ was the most effective for limiting the number of new cankers, but it did not limit expansion of the excised area. Additional physical and fungicidal strategies need to be tested for effective management of anthracnose canker.

I $n$ recent years there has been a rapid expansion of cider apple production in Washington state, with many new plantings occurring west of the Cascades where there is an average reported yield of $36,000 \mathrm{lb} /$ acre and crop value of $\$ 12,960 /$ acre, assuming a fruit price of $\$ 0.36 / \mathrm{lb}$ (Galinato et al., 2014; Northwest Cider Association, 2016). A major obstacle to long-term orchard productivity and continued expansion in western Washington is the widespread occurrence of anthracnose canker on apple, caused by Neofabraea malicorticis (Rahe, 2010; Zang et al., 2011). In the absence of effective management of $N$. malicorticis, anthracnose canker can spread within an entire western Washington orchard in 1 or 2 years, and within 3 or 4 years can kill newly planted trees and structurally weaken established trees (Davidson and Byther, 1992; Garton et al., 2018; Rahe, 2010). Information on cultivar susceptibility and host resistance to anthracnose canker is limited and contradictory (Borecki and Czynczyk, 1985; Braun, 1997), and currently all cider apple cultivars are considered susceptible (British Columbia Ministry of Agriculture, 2016; Pscheidt and Ocamb, 2017).

Neofabraea malicorticis can directly infect intact bark tissue, with most infections occurring through the lenticels (Kienholz, 1939). Stem and trunk infections appear to occur primarily in the autumn but can take place throughout the winter and early spring during mild, moist conditions (Davidson and Byther, 1992; Rahe, 2010). Cankers develop during the autumn and to a lesser extent in the winter. In the following spring, cankers resume development, reaching full size in the summer, and pycnidia that form on the canker margin are the source of inoculum for new infections (Barss, 1925; Creemers, 2014; Rahe, 1997). In midsummer to late autumn, conidia (asexual) are disseminated by rain and wind to other parts of the tree as well as to surrounding trees and fruit, causing new infections (Creemers, 2014). Cankers that overwinter may produce ascospores (sexual) in the spring, which can be carried over substantial distances and may also incite new infections (Powell et al., 1970; Rahe, 1997).

Current recommendations for managing anthracnose canker include 1) excising cankers, and 2) applying fungicides to minimize the occurrence of new infections (Pscheidt and Ocamb, 2017). The reported efficacy of canker excision in managing disease incidence and severity (appearance of new cankers, and expansion of existing cankers) on trees is limited and variable. Byther (1986) reported a $45 \%$ reduction in the occurrence of new cankers 1 year after

\begin{tabular}{llll}
\hline $\begin{array}{l}\text { Units } \\
\begin{array}{l}\text { To convert U.S. to SI, } \\
\text { multiply by }\end{array}\end{array}$ & U.S. unit & SI unit & $\begin{array}{l}\text { To convert SI to U.S., } \\
\text { multiply by }\end{array}$ \\
\hline 0.4047 & acre $(\mathrm{s})$ & $\mathrm{ha}$ & 2.4711 \\
29.5735 & $\mathrm{fl} \mathrm{oz}$ & $\mathrm{mL}$ & 0.0338 \\
0.3048 & $\mathrm{ft}$ & $\mathrm{m}$ & 3.2808 \\
2.54 & inch $(\mathrm{es})$ & $\mathrm{cm}$ & 0.3937 \\
25.4 & inch(es) & $\mathrm{mm}$ & 0.0394 \\
6.4516 & inch ${ }^{2}$ & $\mathrm{~cm}^{2}$ & 0.1550 \\
0.4536 & $\mathrm{lb}$ & $\mathrm{kg}^{2}$ & 2.2046 \\
1.1209 & $\mathrm{lb} / \mathrm{acre}$ & $\mathrm{kg} \cdot h a^{-1}$ & 0.8922 \\
1.6093 & mile(s) & $\mathrm{km}$ & 0.6214 \\
28.3495 & $\mathrm{Oz}$ & $\mathrm{g}$ & 0.0353 \\
$\left({ }^{\circ} \mathrm{F}-32\right) \div 1.8$ & ${ }^{\circ} \mathrm{F}$ & ${ }^{\circ} \mathrm{C}$ & $\left({ }^{\circ} \mathrm{C} \times 1.8\right)+32$
\end{tabular}


canker excision (CE) treatment, while Rahe (2010) observed no reduction in the number of new cankers. The reported efficacy of applying cauterization (CAU) and/or fungicidal treatments to cankers or excised areas is also quite variable. Studies of pathogens that incite similar canker diseases on fruit trees, such as bacterial canker (Pseudomonas syringae), phytophthora canker (Phytophthora citricola), and botryosphaeria canker (Botryosphaeria sp.), have demonstrated that CAU or chemical treatments applied directly to cankers or to the excised area following $\mathrm{CE}$ can reduce or prevent infections (BrownRytlewski and McManus, 2000; El-Hamalawi and Menge, 1994; Fawcett, 1915; Hawkins, 1976). Studies on anthracnose canker specifically have reported that the effect of CAU treatments in limiting disease progression does not last more than 1 year after application (Byther, 1986; Rahe, 2010). Chemical treatments to control Neofabraea species are predominantly copper-based fungicides (Barss and Mote, 1931; Childs, 1927; Henriquez et al., 2006; Spotts et al., 2009). Byther (1986) found that basic copper sulfate reduced the number of new cankers on trees by $50 \%$ when an application was made once in midOctober followed by a second dormant application in mid-February. In contrast, an in vitro study found that copper-based fungicides were ineffective to control $N$. malicorticis (Rahe, 1997). Early 20th century recommendations for managing anthracnose canker included applying

\begin{tabular}{l}
\hline Funding and support for this project are gratefully \\
acknowledged from Washington State University \\
Extension, Washington State Commission on Pes- \\
ticide Registration, Northwest Cider Association, \\
Northwest Agricultural Research Foundation, \\
and USDA NIFA Hatch projects 1000194 and \\
1017286.
\end{tabular}

The mention of a trademark, proprietary product, or company does not constitute a guarantee or warranty of the product by the USDA-ARS and does not imply its approval to the exclusion of other products or companies that also may be suitable.

${ }^{1}$ Department of Horticulture, Washington State University Northwestern Washington Research and Extension Center, 16650 State Route 546, Mount Vernon, WA 98273 ,

${ }^{2}$ U.S. Department of Agriculture-Agricultural Research Service, Physiology and Pathology of Tree Fruits Research Laboratory, 1104 N. Western Avenue, Wenatchee, WA 98801

${ }^{3}$ Department of Mathematics and Statistics, Washington State University, Pullman, WA 99164

${ }^{4}$ Corresponding author. E-mail: milesc@wsu.edu.

https://doi.org/10.21273/HORTTECH04148-18
Bordeaux mixture (BM) (basic copper sulfate and calcium hydroxide) after CE (Cordley, 1900; Zeller, 1926). There are no published data on the efficacy of $\mathrm{CE}$ plus $\mathrm{BM}$ or other copper-based products to control anthracnose canker.

Anthracnose canker is an economic threat to cider apple production in western Washington and growers are in need of an effective management plan. Cider apple growers in the region are currently using several physical and fungicidal treatments alone and in combination in an attempt to control anthracnose canker during the winter, although there is no evidence of treatment efficacy. The objective of this study was to assess the efficacy of various treatments on existing cankers on cider apple trees in western Washington, and to assist growers to eliminate the application of ineffective and costly treatments.

\section{Materials and methods}

Three experiments that included a total of seven treatments were carried out over 3 years, from 2015 to 2017 , in an experimental cider apple orchard at Washington State University (WSU) Northwestern Washington Research and Extension Center (NWREC) in Mount Vernon, WA. Five treatments were applied in 2015 and 2016, and the 2016 experiment included one additional treatment (Table 1). In 2017, three of the same treatments were applied as in 2016 plus one additional treatment. The 1 -acre orchard included three to six trees each of 60 cultivars that were naturally infested with $N$. malicorticis (Zang et al., 2011). Trees were nursery-budded in Aug. 2012, planted at WSU NWREC in Apr. 2014, and were in their second growing season in 2015. Trees were trained to a tallspindle trellis system, spaced $6 \mathrm{ft}$ inrow and $14 \mathrm{ft}$ between rows. The diameter of the central leader was $\approx 0.5$ inch in $2015,0.7$ inch in 2016 , and 0.8 inch in 2017. Weather data (mean air temperature, relative humidity, total precipitation, and solar radiation) were recorded every $5 \mathrm{~s}$ and summarized every $15 \mathrm{~min}$ by WSU AgWeatherNet, the monitored Mount Vernon station located $\approx 0.4$ miles from the cider apple research orchard (WSU, 2017). Disease distribution, as defined by appearance and number of anthracnose cankers, was uniform across cultivars in the orchard with $77 \%$ of trees in the orchard infested with three or more cankers per tree at the beginning of the study each year; this level of infection is representative of the severity of this disease in this region. Trees selected for the experiment each year bore anthracnose cankers of similar size, and different trees were included in the experiment each year. The experimental design did not block the treatments by cultivar as it was not feasible given the orchard design, and there is no evidence in the literature that there is any cultivar effect on disease incidence or severity. Treatments were assigned to trees in a completely randomized fashion with 10 single-tree replicates per treatment. All cankers on each tree received the assigned physical and/or fungicidal treatment, but only one randomly selected canker on the central leader of each tree was monitored in each experiment. All cankers on the trees were new each year; that is, they appeared within a few months before each experiment was initiated. Treatments were applied once each year, in December; as spores are released from cankers during the late summer and fall (Pscheidt and Ocamb, 2017), this time of year was selected for this study to test efficacy of treatments when there likely was no new inoculum present to cause new infections.

2015 EXPERIMENT. Fifty trees of 30 cultivars were evaluated: Blanc Mollet, Brown Thorn, Bulmer's Norman, Chisel Jersey, Domaines, Fillbarrel, Finkenwerder Herbstprinz, Frequin Rouge, Granniwinkle, Harry Masters' Jersey, Jouveaux, Kermerrien, Kingston Black, Major, Maude, Mettais, Muscadet de Dieppe, Peau de Vache, Reine des Hatives, Ross Nonpareil, Roxbury Russet, Smith's Cider, Stembridge Jersey, Stoke Red, Sweet Alford, Sweet Coppin, Taylor's, Vilberie, Yarlington Mill, and Zabergau Reinette. Five treatments were applied only once, on $16 \mathrm{Dec}$. 2014: 1) BM only; 2) CE + 0.5\% sodium hypochlorite $(5.25 \%$ sodium hypochlorite, household bleach; James Austin Co., Mars, PA); 3) $\mathrm{CE}+\mathrm{CAU}$; 4) $\mathrm{CE}+\mathrm{CAU}+$ copper hydroxide (Nu-cop 50 DF; Albaugh, Ankeny, IA); and 5) $\mathrm{CE}+$ copper hydroxide. The BM used in this 
experiment was a 10-10-100 ratio, prepared by mixing $10 \mathrm{~g}$ of basic copper sulfate $\left(\mathrm{CuSO}_{4}\right)$ and $10 \mathrm{~g}$ of calcium hydroxide $\left[\mathrm{Ca}(\mathrm{OH})_{2}\right]$ with $100 \mathrm{~mL}$ water; $\approx 2 \mathrm{~mL}$ of the BM was applied with a paint brush ( 1 inch) to the canker. A $0.5 \%$ sodium hypochlorite solution was prepared by mixing 1 part household bleach with 9 parts water, and $\mathrm{l} \mathrm{mL}$ of the solution was applied with a hand-spray bottle. The copper hydroxide was mixed according to label directions, applied at $12 \mathrm{lb} /$ acre with a hand-spray bottle. For CE, the canker was cut out with a pruning knife that was sterilized with $0.5 \%$ sodium hypochlorite before each excision. Following Rahe (2010), healthy tissue beyond the perceived margin of infection was removed as the pathogen may reside in this tissue. The resulting excisions were 1 to $3 \mathrm{~mm}$ beyond the original canker margins, but cambium tissue was present throughout the excision zone. Excised material was removed from the orchard. The CAU treatment was carried out with a selfigniting hand-held propane torch kit (Bernzomatic TS3000 and TX9 14.1-fl oz cylinder; Worthington Industries, Columbus, $\mathrm{OH}$ ). All treated tissue was flamed for $5 \mathrm{~s}$ with the full flamed torch held $\approx 6 \mathrm{~cm}$ from tissue (Fig. 1). Per manufacturer labeling, flame temperature in air was $3600^{\circ} \mathrm{F}$.

2016 EXPERIMENT. Sixty trees of 36 cultivars were evaluated: Amere Forestier, Blanc Mollet, Bramley's Seedling, Bramtot, Breakwell Seedling, Brown Thorn, Brown's Apple, Campfield, Chisel Jersey, Fillbarrel, Frequin Rouge, Golden Russet, Grimes Golden, Jouveaux, Kermerrien, Lambrook Pippin, Major, Medaille D'Or, Mettais, Michelin, Muscat De Bernay, Peau De Vache, Redstreak, Reine des Hatives, Reine des Pommes, Royal Jersey, Stembridge Jersey, Stoke Red, Sweet Alford, Sweet Coppin, Taliaferro, Taylor's, Tom Putt, Whidbey, Yarlington Mill, and Zabergau Reinette. Six treatments were applied only once on 11 Dec. 2015: 1) BM only; 2) CE + $0.5 \%$ sodium hypochlorite; 3$) \mathrm{CE}+$ $\mathrm{CAU}$; 4) $\mathrm{CE}+\mathrm{CAU}+$ copper hydroxide; 5) $\mathrm{CE}+\mathrm{BM}$; and 6) $\mathrm{CE}+$ copper hydroxide (control). Treatments repeated from 2015 were formulated and applied identically. For the new treatment, $\mathrm{CE}+\mathrm{BM}$, the

Table 1. Treatments applied to anthracnose cankers on cider apple trees in 2015, 2016, and 2017.

\begin{tabular}{lr}
\hline Treatment $^{\mathbf{z}}$ & \multicolumn{1}{c}{$\mathbf{Y r}^{\mathbf{y}}$} \\
\hline 1. BM only & 2015,2016 \\
2. CE $+0.5 \%$ sodium hypochlorite & $2015,2016,2017$ \\
3. CE + copper hydroxide & $2015,2016,2017$ \\
4. CE + CAU & 2015,2016 \\
5. CE + CAU + copper hydroxide & 2015,2016 \\
6. CE + BM & 2016,2017 \\
7. CE only & 2017 \\
\hline
\end{tabular}

${ }_{\mathrm{z}} \mathrm{BM}=$ Bordeaux mixture, prepared as $10 \mathrm{~g}(0.35 \mathrm{oz})$ basic copper sulfate, $10 \mathrm{~g}$ calcium hydroxide, and $100 \mathrm{~mL}$ $(3.38 \mathrm{fl} \mathrm{oz})$ water; $\mathrm{CE}=$ canker excision, canker cut out with a pruning knife sterilized with sodium hypochlorite solution $(0.5 \%)$, l part of sodium hypochlorite with 9 parts water applied to excised area with a hand-spray bottle; copper hydroxide, mixed according to label directions, $12 \mathrm{lb} /$ acre $\left(13.45 \mathrm{~kg} \cdot \mathrm{ha}^{-1}\right)$ applied to the excised area with a hand-spray bottle; $\mathrm{CAU}=$ cauterization, carried out with a hand-held propane torch (Worthington Industries, Columbus, $\mathrm{OH}$ ), flame held to the excised area for $5 \mathrm{~s}$.

${ }^{y}$ Treatment application dates were 16 Dec. 2014 for the 2015 experiment, 11 Dec. 2015 for the 2016 experiment, and 13 Dec. 2016 for the 2017 experiment.
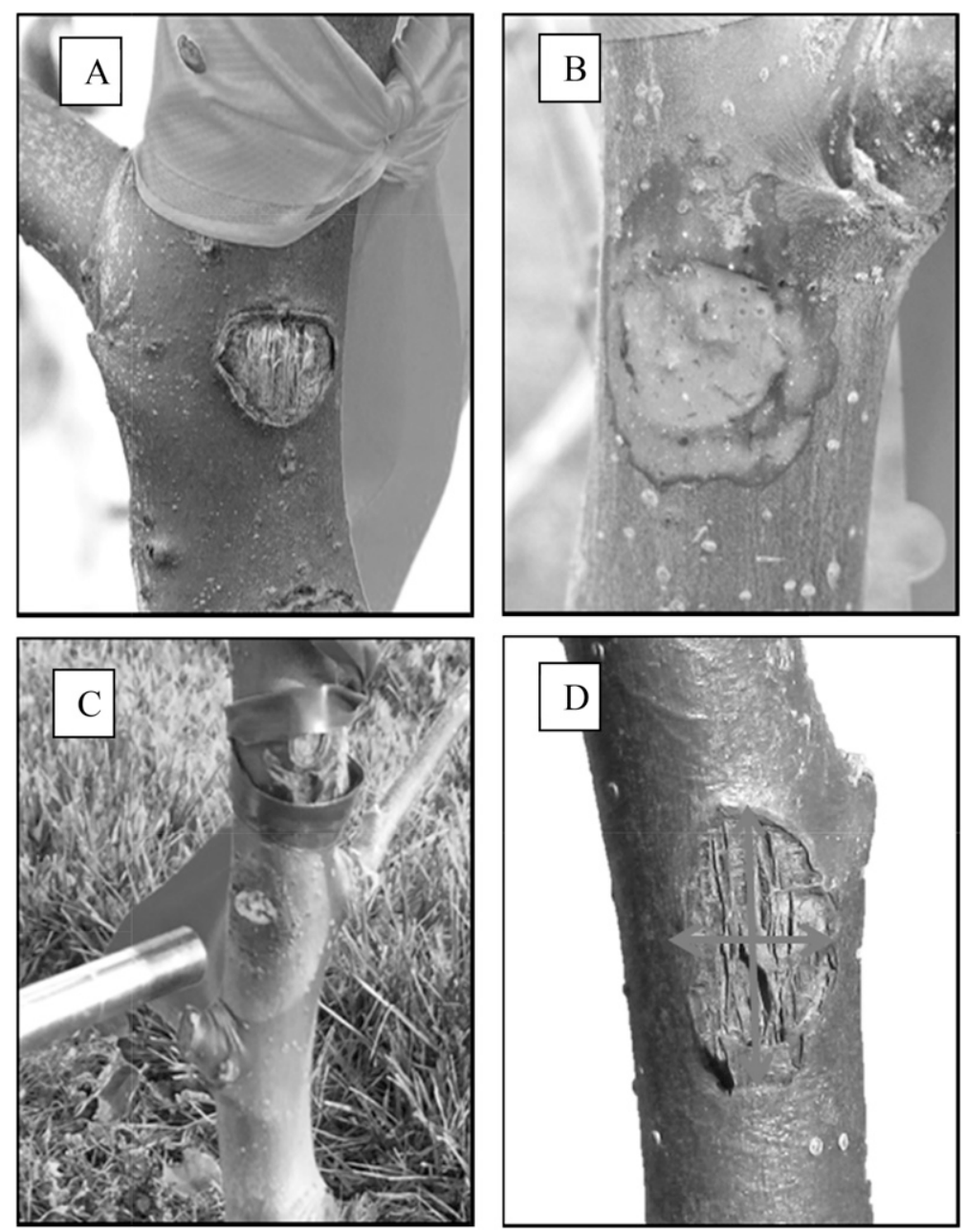

Fig. 1. (A) Anthracnose canker on cider apple tree before treatment application; (B) Bordeaux mix applied to excised canker ( 1 to $3 \mathrm{~mm}$ of tissue beyond the canker margin was removed); (C) cauterization applied to excised canker; and (D) arrows illustrate the area that was measured pre- and posttreatment; $1 \mathrm{~mm}=0.0394$ inch.

canker was cut out with a sterilized pruning knife as described above and the excised area was painted with BM (2 mL).
2017 EXPERIMENT. Forty trees of 26 cultivars were evaluated: Amere de Berthcourt, Ashmead's Kernel, Bouteville, Brown Snout, Brown Thorn, 
Bulmer's Norman, Campfield, Chisel Jersey, Doux Normandie, Fillbarrel, Finkenwerder Herbstprinz, Frequin Rouge, Golden Russet, Harrison, Harry Masters' Jersey, Hewe's Virginia Crab, Liberty, Major, Maude, Puget Spice, Roxbury Russet, Royal Jersey, Russet King, Stembridge Jersey, Stoke Red, and Tom Putt. Four treatments were applied only once on 13 Dec. 2016: 1) CE only; 2) CE + $0.5 \%$ sodium hypochlorite; 3 ) $\mathrm{CE}+$ $\mathrm{BM}$; and 4) CE + copper hydroxide (control). Treatments repeated from the two previous experiments were formulated and applied as described above. "CE only" was added as a treatment, and no CAU treatments were applied in 2017.

Disease severity. Two objective response variables were measured in the three experiments to assess disease severity: 1) initial canker size followed by the size of the treated canker or the excised area, and 2) number of new cankers. Initial canker size (length and width) was measured immediately before treatment application, and then the size of the treated canker or the excised area was measured $3,5,7,9,11,13$, and $15(2017$ only) weeks posttreatment (Fig. 1). The area was calculated using an equation for an ellipse [PI function (Excel 2013; Microsoft, Redmond, WA)], and the size posttreatment was compared with the pretreatment canker size. The number of cankers present on each tree was recorded before treatment application and at the time of the final size measurement of the treated canker or excised area each year. The number of new cankers observed was calculated by taking the difference between preand posttreatment measurements. A subjective response variable, brown streaking indicative of the disease (Byther, 1986; Rahe, 2010), was evaluated in the tissue below the treated canker or the excised area. The surface of the treated canker or the excised area was removed with a sterilized pruning knife, as described above, 15 months posttreatment, on 17 Mar. 2016, 14 Mar. 2017, and 15 Mar. 2018. The amount of cambium tissue that exhibited dark brown streaking was then visually rated on a scale of 0 to 5 where $0=$ no streaking; $\mathrm{l}=1 \%$ to $20 \%$ streaking; $2=21 \%$ to $40 \%$ streaking; $3=41 \%$ to $60 \%$ streaking; $4=61 \%$ to $80 \%$ streaking; and $5=$ more than $81 \%$ streaking. Each year, symptomatic tissue was collected from the selected treated canker or the excised area experiment, five trees per treatment, for pathogen isolation and identification. Tissue was surface sterilized in $0.5 \%$ sodium hypochlorite and rinsed with sterile distilled water, then small sections were plated onto potato dextrose agar [PDA (Difco, Betcon, Dickinson and Co., Sparks, MD)] amended with chloramphenicol (Sigma-Aldrich Co., St. Louis, MO). Plates were incubated at 20 to $22{ }^{\circ} \mathrm{C}$, and cultures were transferred to fresh PDA weekly.

Statistical analysis. All data were analyzed in SAS (version 9.3; SAS Institute, Cary, NC) using proc that was monitored for size in each

mixed procedure. To determine if there was a treatment effect for canker size, data were analyzed as a repeated measures analysis of variance (ANOVA). Treatment and weeks were considered fixed effects and replicates considered random. The assumptions of normality and homogeneity of variances were assessed in all cases using the Shapiro-Wilk test and the Levene's test respectively (using $\alpha=0.05$ ). Canker size data were $\log$ transformed to meet normality and equal variance assumptions. Treatment effects by each year were analyzed by ANOVA and compared using Tukey's honestly significant difference at a $5 \%$ level of significance. For the number of new cankers, which was a discrete count variable, a generalized linear model
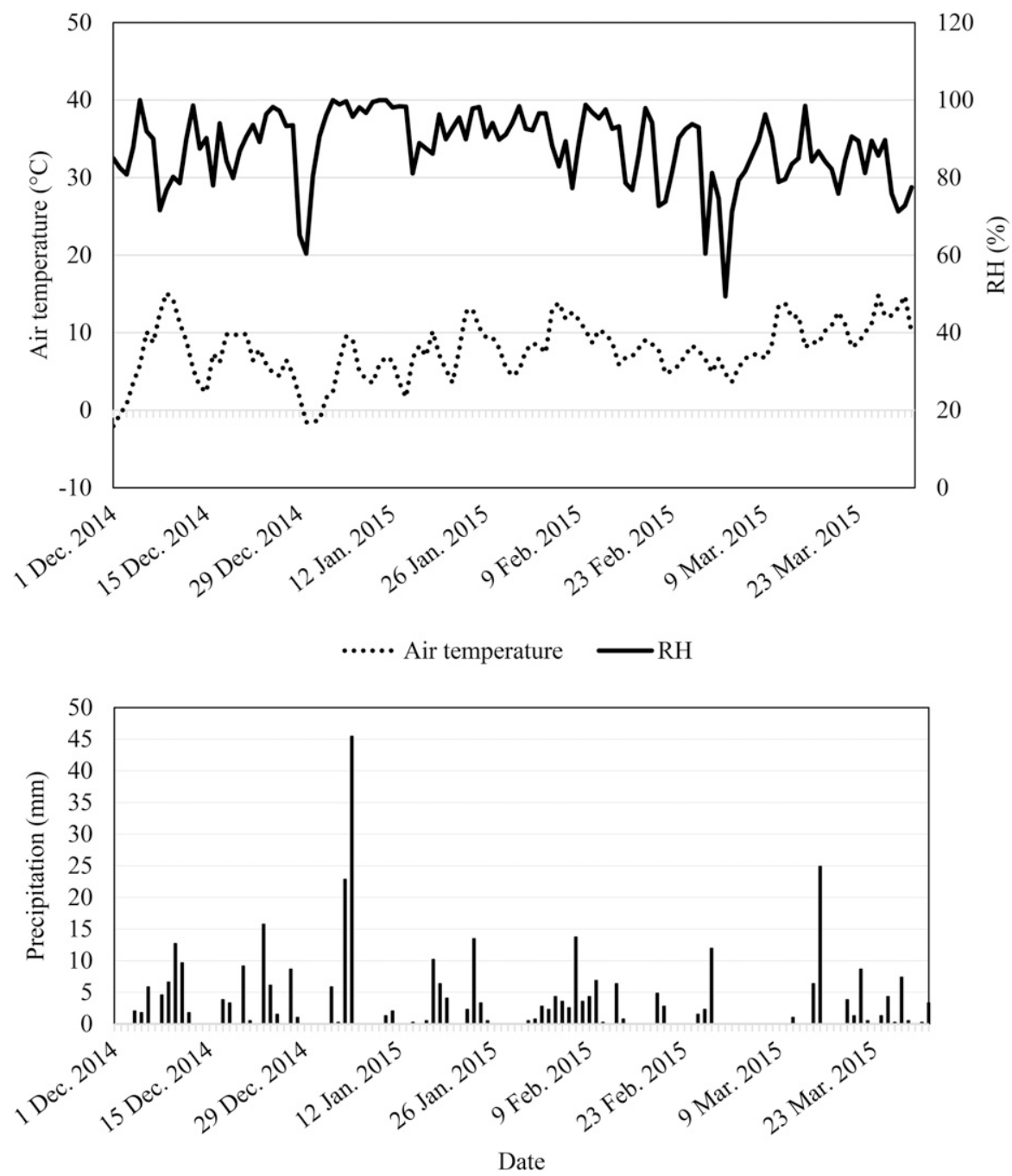

Fig. 2. Mean daily air temperature and relative humidity $(\mathrm{RH})$ and precipitation at Washington State University Northwestern Washington Research and Extension Center in Mount Vernon, WA during the $\mathbf{2 0 1 5}$ experiment on cider apple trees; $\left(1.8 \times{ }^{\circ} \mathrm{C}\right)+32={ }^{\circ} \mathrm{F}, 1 \mathrm{~mm}=0.0394$ inch. 
with a Poisson distribution was used. For tissue streaking rating, an ordinal logistic model was used. Treatment means for the number of new cankers and tissue streaking were compared using Student's $t$ test at a 5\% level of significance.

The evidence in the literature regarding cultivar effect for anthracnose canker incidence or severity is limited and contradictory, and currently all apple cultivars, including cider cultivars, are considered to be susceptible to $N$. malicorticis (British Columbia Ministry of Agriculture, 2016; Creemers, 2014; Pscheidt and Ocamb, 2017). Therefore, this study was not designed for testing a cultivar effect on canker size or treatment response, and cultivar effect was assessed post hoc by comparing data for each treatment across the cultivars where possible. Data were subset by each treatment and year and analyzed as a repeated measures design with replicates random. Similarly, to determine if there was a year effect, data for the two treatments that were applied all 3 years $(\mathrm{CE}+0.5 \%$ sodium hypochlorite, $\mathrm{CE}+$ copper hydroxide) were analyzed as repeated measures ANOVA, with year, treatment, and weeks as fixed effects and replicate as a random effect.

\section{Results}

Climate. Daily mean air temperature tended to be lower each consecutive year, and was $7.7^{\circ} \mathrm{C}$ in 2015 and $4.2{ }^{\circ} \mathrm{C}$ in 2017 (Figs. 2-4). Relative humidity also was lower each year, and was $88 \%$ in 2015 and $81 \%$ in 2017 . Daily mean precipitation was higher in the 2016 experiment (3.9 $\mathrm{mm}$ average) than in 2015 and 2017 (2.8 $\mathrm{mm}$ average).

Disease SEVERITY. There was a year effect $(P<0.0001)$ for the two treatments that were applied in all three experiments, $\mathrm{CE}+0.5 \%$ sodium hypochlorite and $\mathrm{CE}+$ copper hydroxide. Size of cankers in 2016 was smaller than in the other 2 years $[P=$ 0.001 (data not shown)]. However, there were no differences in canker size among treatments within a year. Initial mean canker size was $0.49 \mathrm{~cm}^{2}$ in $2015(P=0.92), 0.26 \mathrm{~cm}^{2}$ in 2016 $(P=0.17)$, and $0.38 \mathrm{~cm}^{2}$ in 2017 $(P=0.88)$.

There were significant effects for treatment, week, and the interaction
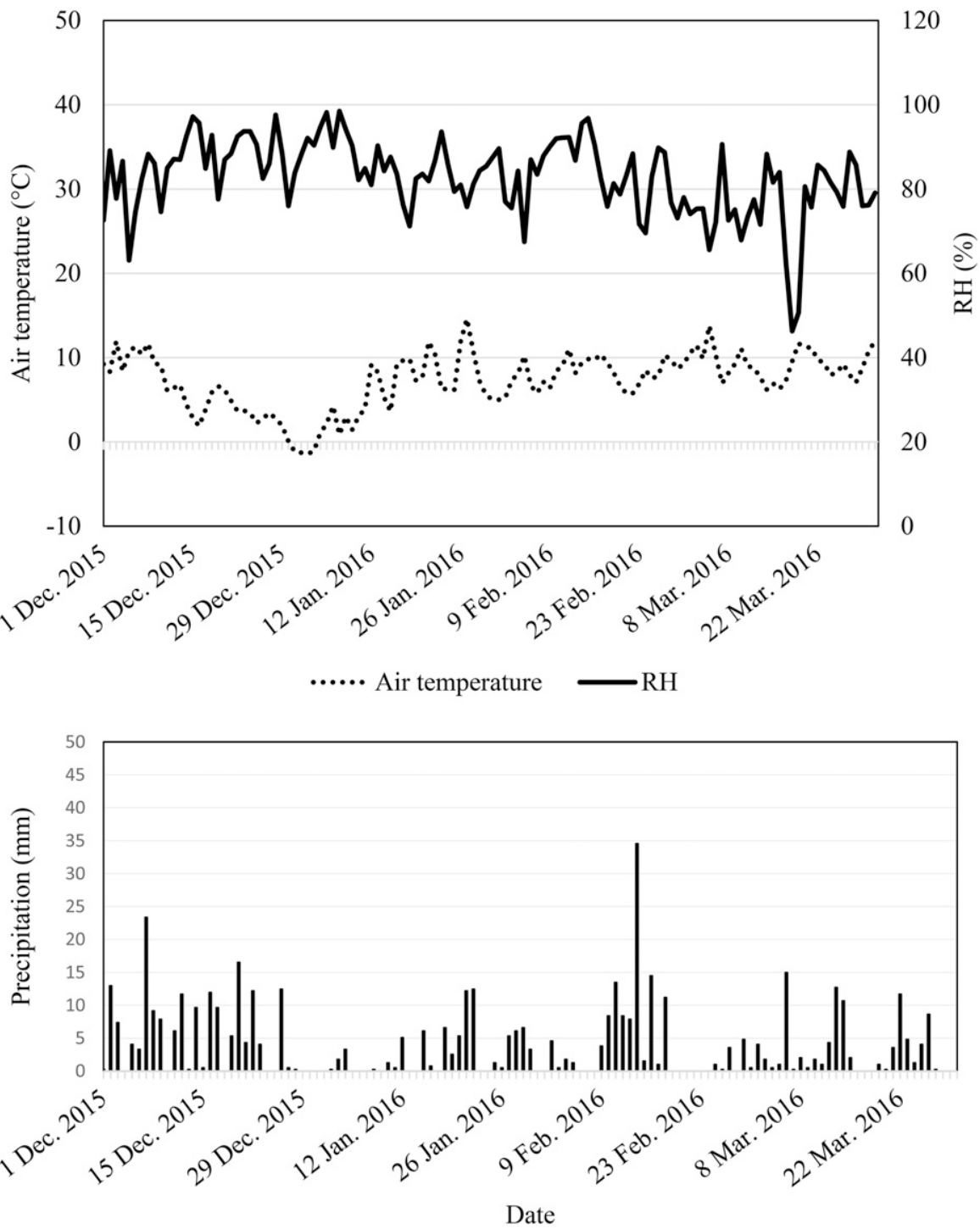

Fig. 3. Mean daily air temperature and relative humidity $(\mathrm{RH})$ and precipitation at Washington State University Northwestern Washington Research and Extension Center in Mount Vernon, WA during the 2016 experiment on cider apple trees; $\left(1.8 \times{ }^{\circ} \mathrm{C}\right)+32={ }^{\circ} \mathrm{F}, 1 \mathrm{~mm}=\mathbf{0 . 0 3 9 4}$ inch.

of treatment and week for size of the treated canker or excised area in 2015 and 2016 , and the relative response to each treatment was similar both years (Fig. 5). The size of the excised area increased over time compared with the pretreatment area $(P<$ $0.0001)$, while there was no increase in the size of the treated canker. For treatments without CAU, the size of the excised area increased on average 4 -fold in 2015 and 3 -fold in 2016. For the two treatments that included CAU, the size of the excised area increased on average 16-fold in 2015 and 40-fold in 2016. In 2017 there was only a significant effect due to treatment $(P=0.03)$. Increase in canker size was greatest with the
CE only treatment (5-fold), and was lowest with the $\mathrm{CE}+\mathrm{BM}$ treatment (3-fold) (Fig. 6). Cultivar effect on canker size pretreatment and the size of the treated canker or excised area posttreatment was not significant $(P>0.05)$ for any treatments except $\mathrm{CE}+0.5 \%$ sodium hypochlorite $[P=$ 0.008 (data not shown)]. The CE only treatment, evaluated solely in 2017, had inadequate replicates to test for cultivar effect. Overall, there was not a cultivar effect to influence the efficacy of the treatments.

The number of new cankers recorded 13-15 weeks after treatment application differed across experiments $(P=0.03)$, but there were no differences within the experiment 

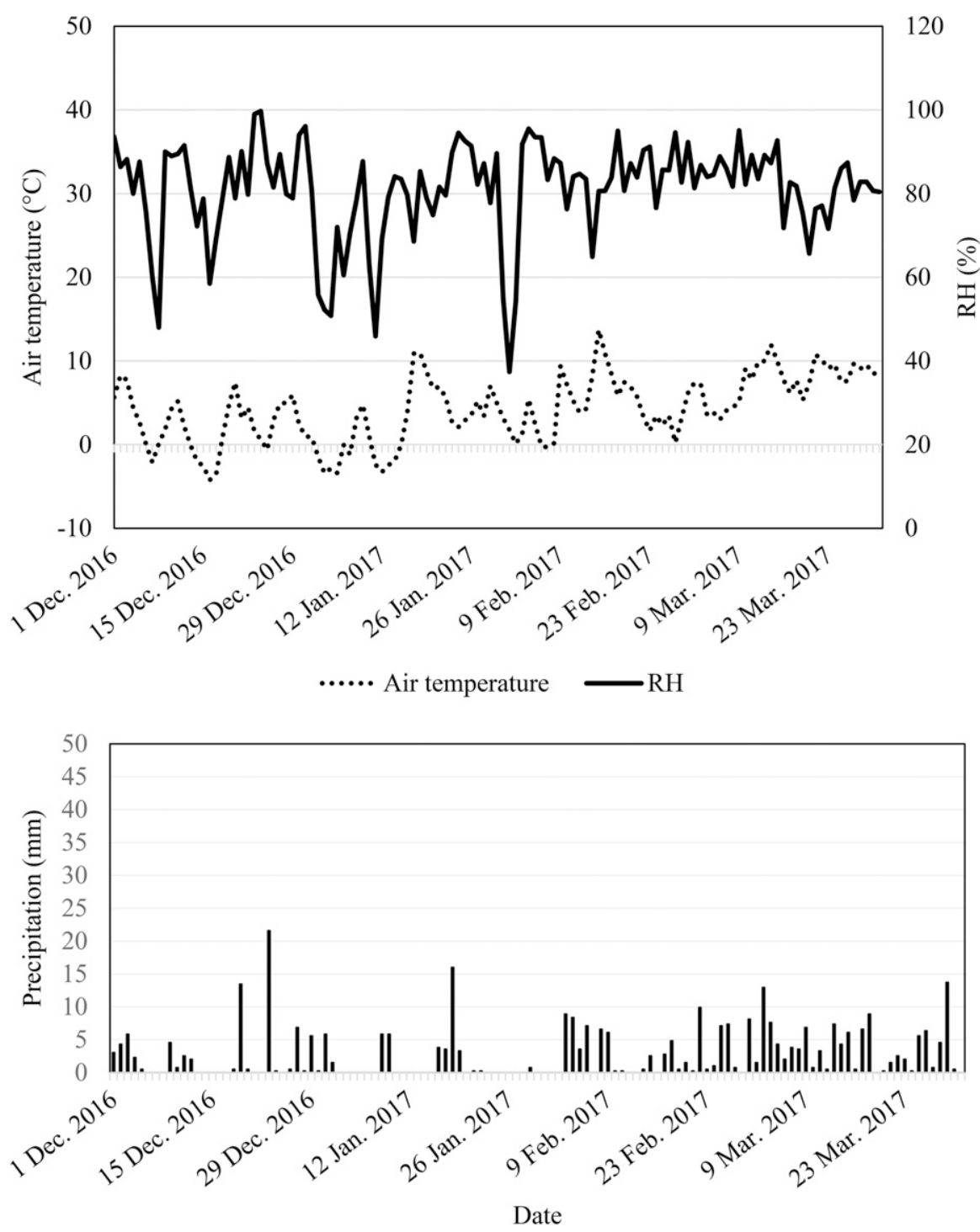

Fig. 4. Mean daily air temperature and relative humidity $(\mathrm{RH})$ and precipitation at Washington State University Northwestern Washington Research and Extension Center in Mount Vernon, WA during the 2017 experiment on cider apple trees; $\left(1.8 \times{ }^{\circ} \mathrm{C}\right)+32={ }^{\circ} \mathrm{F}, 1 \mathrm{~mm}=0.0394$ inch.

in 2015 or $2017(P=0.83$ and 0.16 , respectively) (Table 2). In 2016, the treatments BM only and CE + BM had on average five more new cankers, while the treatments $\mathrm{CE}+0.5 \%$ sodium hypochlorite and $\mathrm{CE}+\mathrm{CAU}+$ copper hydroxide had two on average $(P=0.01)$.

Fifteen months after treatment application, dark brown streaks indicative of the disease were observed in the cambium tissue below the treated cankers and excised areas for all treatments each year (Table 2). Ratings ranged from 1 to 3 ( $1 \%$ to $60 \%$ ) and did not differ due to treatment in any year $(P=0.21,0.12$, and 0.06 , respectively).

\section{Discussion and conclusions}

The current recommendation for managing established anthracnose cankers in the Pacific Northwest is excising symptomatic tissue during dry weather (Pscheidt and Ocamb, 2017; WSU, 2016). This study tested the treatments that are commonly applied to anthracnose cankers, and measured disease severity when, in theory, there was no new inoculum present, as spores are released from cankers during the late summer and fall (Pscheidt and Ocamb, 2017). The size of the excised area increased with the CE only treatment, and CE alone did not prevent new cankers from developing on the trees. This result was similar to observations of Rahe (2010) where CE did not limit the number of new cankers that developed the following year. In the current study, CE followed by an application of $0.5 \%$ sodium hypochlorite had the lowest increase in size of the excised area compared with the other CE treatments, and the fewest number of new cankers. However, some cultivars appeared to show sensitivity to the solution by developing dark black tissue around the margin of the excised area, and this response likely accounted for the cultivar effect with this treatment. Other reports have indicated that sodium hypochlorite loses its disinfecting properties within $24 \mathrm{~h}$ of application (Ono, 2006), thereby reducing its ability to prevent infection of the wound. Sodium hypochlorite may be more effective if it is applied to the excised area and then covered with BM (Zaiger, 1968; Zaiger and Zentmyer, 1965); however, this may exacerbate sensitivity to the sodium hypochlorite solution in some cultivars.

There was also a relatively low expansion of the excised area when $\mathrm{CE}$ was followed by an application of copper hydroxide. The spray application of copper hydroxide was relatively quick and only required a small amount of product, which are important cost considerations. However, some cultivars developed dark black tissue surrounding the margin of the excised area, similar to that observed with the $\mathrm{CE}+0.5 \%$ sodium hypochlorite treatment. This may have been a phytotoxicity response or an effect of a host defense mechanism. The size of the excised area treated with $\mathrm{BM}$ was similar to other CE plus chemical treatments in this study, but more new cankers developed with BM than with other treatments. Only a single application of BM was used in this study (as the product was not washed off by rain events), and either a different timing of the application or more applications may be needed to reduce new canker development. In the current study, application of BM was by hand with a paint brush, which was time consuming and laborious. This application method is likely not cost-effective, and it may be more efficient to spray BM on affected areas or the entire tree, but efficacy would need to be tested. Some growers have 


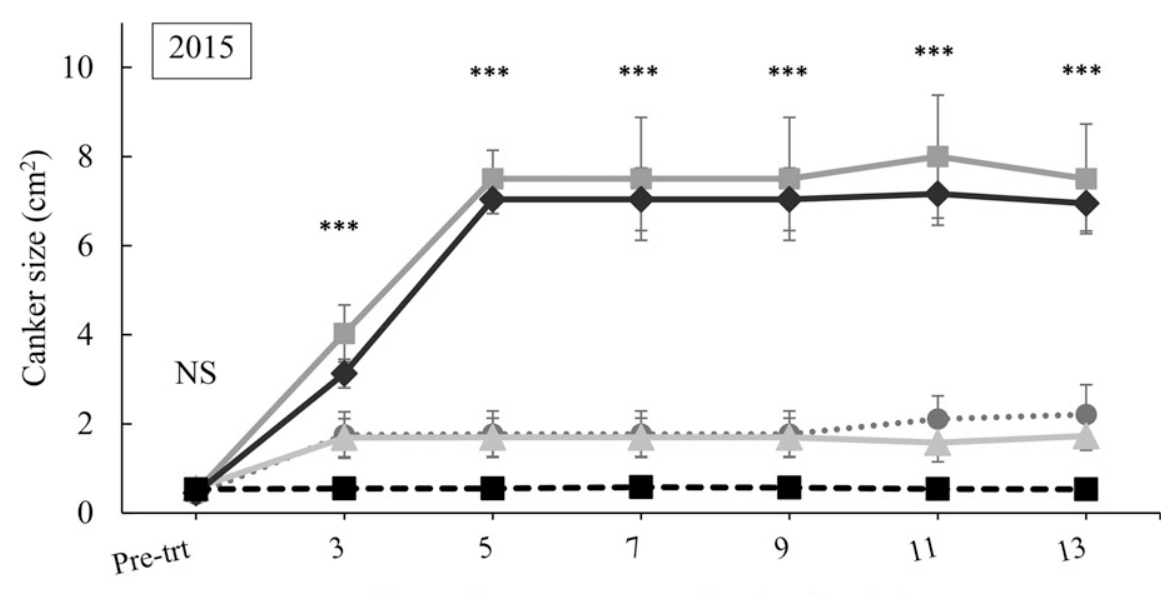

Time after treatment application (weeks)

$$
\begin{aligned}
& \cdots \cdot \mathrm{CE}+10 \% \text { sodium hypochlorite }-\mathrm{CE}+\text { copper hydroxide (control) } \\
& -\mathrm{CE}+\mathrm{CAU} \\
& -\mathrm{C}-\mathrm{CE}+\mathrm{CAU}+\text { copper hydroxide }
\end{aligned}
$$

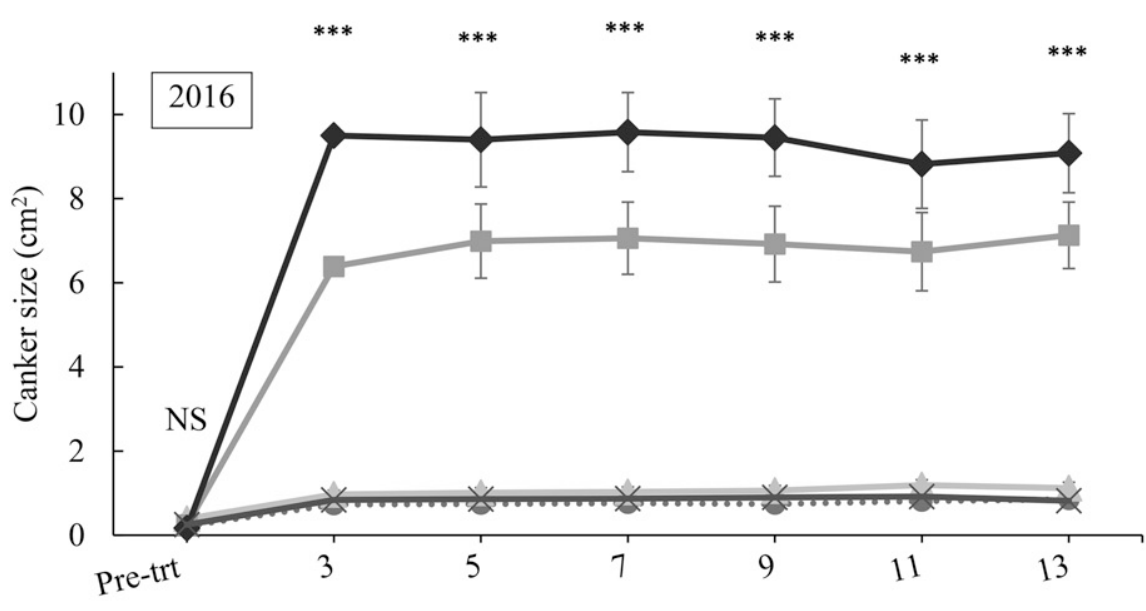

Time after treatment application (weeks)

$$
\begin{aligned}
& \because \cdot \mathrm{CE}+10 \% \text { sodium hydroxide } \\
& -\mathrm{CE}+\mathrm{CAU} \\
& \leftarrow \mathrm{CE}+\text { Bordeaux mixture }
\end{aligned}
$$

$-\mathrm{CE}+$ copper hydroxide (control) $\neg \mathrm{CE}+\mathrm{CAU}+$ copper hydroxide

Fig. 5. Effect of Bordeaux mixture only, or canker excision (CE) with a subsequent application of cauterization (CAU) and/or chemical treatment, on the mean size of the treated canker or excised area on cider apple trees in 2015 (top) and 2016 (bottom). Treatments were applied once each year (on 16 Dec. 2014 and 11 Dec. 2015 , respectively) to different trees that were naturally infested with anthracnose canker. Each data point represents a mean of 10 replicates \pm SE, pretreatment (Pretrt) to 13 weeks posttreatment. Some error bars not visible due to masking by data point symbols. NS indicates nonsignificant differences, and *,$* * * *$ indicate significant differences among treatments at each measurement time at $P \leq 0.05$, 0.01 , and 0.0001 , respectively, as determined by Tukey's honestly significant difference test; $1 \mathrm{~cm}^{2}=0.1550$ inch $^{2}$.

been cauterizing the excised area, although there is no evidence to support the efficacy of this treatment. In the current study, CE plus CAU caused the most damage to the area of the tree that was treated, and the

number of new cankers was not reduced. CAU of the excised area followed by copper hydroxide also did not reduce new canker development. This finding is similar to Byther (1986) that reported CE plus CAU did not limit canker disease incidence or severity in the year following treatment application. Thus, CAU can be eliminated from an anthracnose canker management plan.

For all treatments in this study, 15 months after treatment application, brown streaking was observed in the tissue directly below treated cankers and where cankers had been excised. Streaking occurred despite removing all visible symptoms of fungal infection in the cambium plus an additional 1 to $3 \mathrm{~mm}$ of healthy tissue at the time of treatment application. Others have reported that $N$. malicorticis colonizes host tissue beyond the sites of visible symptoms (Byther, 1986; Rahe, 2010). Thus, it may be necessary to extend the excision even further to remove fungal mycelium that may be present. Although $N$. malicorticis was not successfully isolated from symptomatic cambium tissue in the current study, symptom morphology aligned with descriptions of $N$. malicorticis by Byther (1986) and Rahe (2010). While streaking may have been due to injury of the cambium cells caused by the treatments, symptoms were present even when cankers were not removed. Streaking also occurred when cankers where excised and no fungicide was applied. It is possible that toxicants may have diffused or were translocated downward from the site of treatment application, causing damage to the cambium tissue. Further studies are needed to determine the cause of the streaking found under the cankers and the excised areas.

The climatic conditions were mildly cold and moist during the winter months when the current study was carried out. These conditions mirrored those found to be favorable for disease incited by $N$. malicorticis as reported by Hortová et al., (2014), Miller (1932), and Spotts (1985). The study period of 2016 tended to have the highest average precipitation and the greatest number of new cankers, but the initial size of cankers was smaller than in the other 2 years of this study. Little is known regarding the impact of weather conditions (temperature, precipitation, relative humidity, and solar radiation) on $N$. malicorticis incidence and severity. Measuring climate data during future studies may help to explain treatment results. 


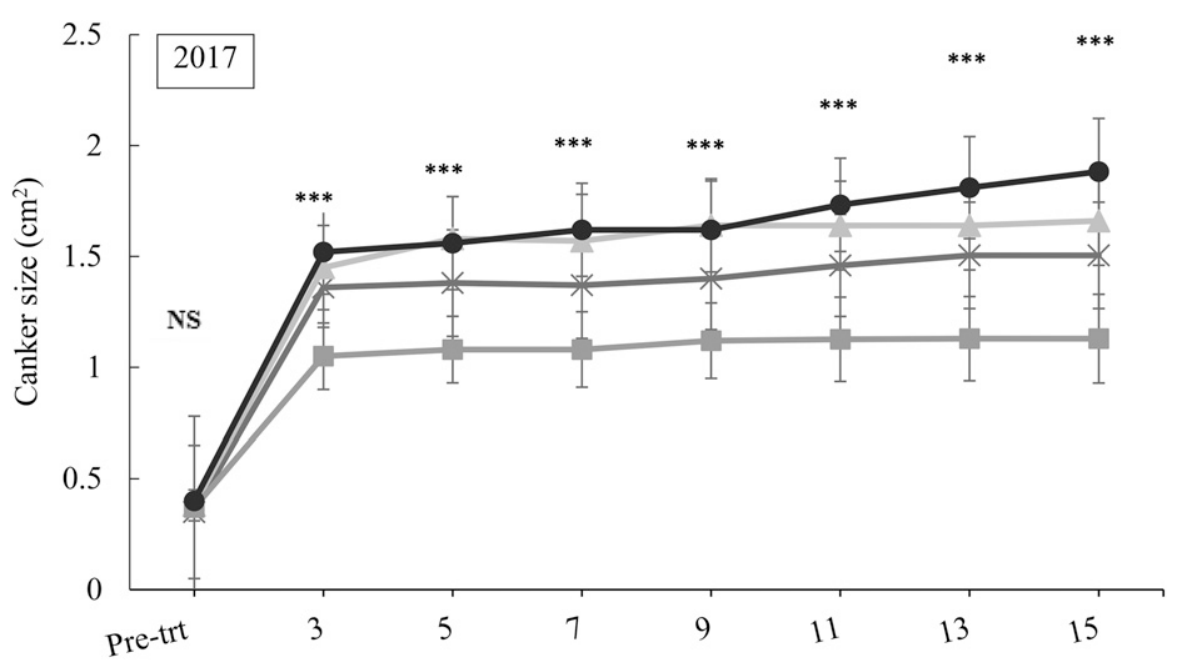

Time after treatment application (weeks)

$\leftarrow \mathrm{CE}+10 \%$ sodium hypochlorite
$-\mathrm{CE}+$ Bordeaux mixture

Fig. 6. Effect of canker excision (CE) with and without a subsequent chemical application on the mean size of the excised area on cider apple trees in 2017. Treatments were applied once (on 13 Dec. 2016) to different trees that were naturally infested with anthracnose canker. Each data point represents a mean of 10 replicates \pm SE, pretreatment (Pre-trt) to 13 weeks posttreatment. Some error bars not visible due to masking by data point symbols. Ns indicates nonsignificant differences, and *,$* * * *$ indicate significant differences among treatments at each measurement time at $P \leq 0.05,0.01$, and 0.0001 , as determined by Tukey's honestly significant difference test; $1 \mathrm{~cm}^{2}=0.1550$ inch $^{2}$.

Table 2. The mean number of new cankers on cider apple trees observed in 2015, 2016 (both 13 weeks posttreatment application), and 2017 (15 weeks posttreatment application), and mean severity rating of brown streaking $15 \mathrm{mo}$. after treatment application in each experiment.

\begin{tabular}{|c|c|c|c|c|c|c|}
\hline \multirow[b]{2}{*}{ Treatments $^{\mathrm{z}}$} & \multicolumn{3}{|c|}{ New cankers (no. $)^{\mathrm{y}}$} & \multicolumn{3}{|c|}{ Brown streaking ( $1-5$ scale $)^{x}$} \\
\hline & 2015 & 2016 & 2017 & 2015 & 2016 & 2017 \\
\hline BM only & 2 & $5 \mathrm{a}^{\mathrm{w}}$ & $-\mathrm{v}$ & 2 & 3 & - \\
\hline $\begin{array}{l}\mathrm{CE}+0.5 \% \text { sodium } \\
\text { hypochlorite }\end{array}$ & 2 & $2 \mathrm{~b}$ & 1 & 2 & 2 & 3 \\
\hline $\mathrm{CE}+$ copper hydroxide & 3 & $3 a b$ & 1 & 2 & 2 & 2 \\
\hline $\mathrm{CE}+\mathrm{CAU}$ & 2 & $4 \mathrm{ab}$ & - & 3 & 2 & - \\
\hline $\begin{array}{l}\mathrm{CE}+\mathrm{CAU}+\text { copper } \\
\text { hydroxide }\end{array}$ & 4 & $2 \mathrm{~b}$ & - & 3 & 3 & - \\
\hline $\mathrm{CE}+\mathrm{BM}$ & - & 5 a & 1 & - & 3 & 1 \\
\hline CE only & - & - & 1 & - & - & 2 \\
\hline$P$ value & 0.83 & 0.01 & 0.16 & 0.21 & 0.12 & 0.06 \\
\hline
\end{tabular}

${ }^{\mathrm{z}} \mathrm{BM}=$ Bordeaux mixture, $\mathrm{CE}=$ canker excision, $\mathrm{CAU}=$ cauterization

${ }^{\mathrm{y}}$ Calculated as the difference in cankers on each treated tree at the time of the final canker size measurement and initial observation pretreatment.

${ }^{x}$ Brown streaking rating, specifically area of dark brown streaks in the cambium tissue, was rated on a scale of 0 to 5 , where: $0=$ no streaking; $l=1 \%$ to $20 \%$ streaking; $2=21 \%$ to $40 \%$ streaking; $3=41 \%$ to $60 \%$ streaking; $4=61 \%$ to $80 \%$ streaking; and $5=$ more than $80 \%$ streaking.

${ }^{w}$ Different letters in a given column indicate significant differences $(P<0.05)$, as determined by Student's $t$-test. "Treatment not applied in the given experiment.

None of the treatments evaluated in this study reduced the occurrence of new infections 13-15 weeks after application. It is important to note that new cankers observed in the current study could have been latent infections that were not evident at the time the tree was treated. Alternatively, new cankers could be a result of new infections occurring after treatments were applied. In both cases, this study shows that the pathogen appears to be active throughout the dormant season in the western Washington maritime climate. Thus, a year-round management plan is needed, potentially including applying protectant fungicides in the autumn and/or winter. Future research should evaluate $\mathrm{CE}$ and fungicide applications to the entire tree throughout the year, and additional fungicide chemistries should be evaluated to prevent pathogen resistance to copperbased products that are currently used extensively in some orchard spray programs. While results from this study for the most part indicate no cultivar effect on disease susceptibility or incidence and severity, some cultivars displayed sensitivity to applications of $0.5 \%$ sodium hypochlorite and copper hydroxide. Future studies should target cultivar effects for disease resistance and chemical treatment.

\section{Literature cited}

Barss, H.P. 1925. Northwestern apple tree anthracnose canker and fruit rot (Neofabraea malicorticis). Oregon State Agr. College Ext. Serv. Circ. 220.

Barss, H.P. and D.C. Mote. 1931. Orchard protection program for Oregon. Oregon State Agr. College Ext. Serv. Bul. 431 .

Borecki, Z. and A. Czynczyk. 1985. Susceptibility of apple cultivars to bark canker diseases. Acta Agrobot. 38:49-59.

Braun, P.G. 1997. Distribution and severity of anthracnose canker and European canker of apple in Kings County, NS. Can. J. Plant Pathol. 78:78-82.

British Columbia Ministry of Agriculture. 2016. Anthracnose and perennial canker of apple. 27 Mar. 2017. <http://www2. gov.bc.ca/assets/gov/farming-naturalresources-and-industry/agriculture-andseafood/animal-and-crops/plant-health/ phu-anthracnose-pc.pdf $>$.

Brown-Rytlewski, D. and P.S. McManus. 2000. Virulence of Botryosphaeria dothidea and Botryosphaeria obtusa on apple and management of stem cankers with fungicides. Plant Dis. 84:1031-1037.

Byther, R.S. 1986. Apple anthracnose. Western Cascade Tree Fruit Nwsl 3:6-8.

Childs, L. 1927. Perennial canker of apples. Annu. Rpt. Oregon Hort. Soc. 19:108-117.

Cordley, A.B. 1900. Apple tree anthracnose: A new fungus disease Oregon Agr. Expt. Sta. Bul 60. 
Creemers, P. 2014. Anthracnose canker and perennial cankers, p. 51-53. In: T. Sutton, H. Aldwinckle, A. Agnello, and J. Walgenbach (eds.). Compendium of apple and pear diseases, 2nd ed. APS Press, St. Paul, MN.

Davidson, R. and R.S. Byther. 1992. Apple anthracnose: Bull's-eye rot. Washington State Univ. Ext. Bul. 0940.

El-Hamalawi, Z.A. and J.A. Menge. 1994. Effect of wound age and fungicide treatment of wounds on susceptibility of avocado stems to infection by Phytophthora citricola. Plant Dis. 78:700-704.

Fawcett, H.S. 1915. Melaxuma of the walnut: Juglans regia. Univ. California. Bul. 261.

Galinato, S.P., K. Gallardo, and C.A. Miles. 2014. 2013 Cost estimation of establishing a cider apple orchard in western Washington. Washington State Univ. Ext. Publ. FS141E.

Garton, W.J., L.W. DeVetter, M. Mazzola, and C.A. Miles. 2018. A review of Neofabraea malicorticis biology and management of anthracnose canker in apple orchards in the maritime Pacific Northwest. J. Amer. Pomol. Soc. 72:113-121.

Hawkins, J.E. 1976. A cauterization method for the control of cankers caused by Pseudomonas syringae bacterial blast in stone fruit trees apricot. Plant Dis. Rptr. 60:60-61.

Henriquez, J.L., D. Sugar, and R. Spotts. 2006. Induction of cankers on pear tree branches by Neofabraea alba and $N$. perennans and fungicide effects on conidial production on cankers. Plant Dis. 90:481-486.
Hortová, B., D. Novotny, and T. Erban. 2014. Physiological characteristics and pathogenicity of eight Neofabraea isolates from apples in Czechia. Eur. J. Hort. Sci. 79:327-334.

Kienholz, J.R. 1939. Comparative study of the apple anthracnose and perennial canker fungi. J. Agr. Res. 59:635-665.

Miller, E.V. 1932. Some physiological studies of Gleosporium perennans and Neofabraea malicorticis. J. Agr. Res. 45:65-77.

Northwest Cider Association. 2016. Northwest cider survey 2015. 3 Mar. 2018. <http://www.nwcider.com/ northwest-cider-survey-2015/>.

Ono, M. 2006. Everything you always wanted to know about bleach but were afraid to ask. 3 Mar. 2018. <https://www. scripps.edu/newsandviews/e_20060213/ bleach.html>.

Powell, D., B. Johnson, and E.G. Sharvelle. 1970. Diseases of apples and pears in the Midwest. North Central Reg. Ext. Publ. 16.

Pscheidt, J.W. and C.M. Ocamb. 2017. Apple (Malus spp.) anthracnose (Bull'seye rot). Oregon State Univ. 23 Mar. 2017. <https://pnwhandbooks.org/ plantdisease/host-disease/apple-malusspp-anthracnose-bulls-eye-rot $>$.

Rahe, J.E. 1997. Anthracnose canker of apples: Put away the sprayer and get out the knife and brush. Cider Press 10(2):6-9.

Rahe, J.E. 2010. Anthracnose canker webinar. 23 Mar. $2017 .<$ http:// fruitgrowersnews.com / news / anthracnose-webinar-educates-growers/>.
Spotts, R.A. 1985. Environmental factors affecting conidial survival of pear decay fungi. Plant Dis. 69:391-392.

Spotts, R., K. Seifert, K. Wallis, D. Sugar, C.L. Xiao, M. Serdani, and J. Henriquez. 2009. Description of Cryptosporiopsis kienbolzii and species profile of $\mathrm{Neo}$ fabraea in major pome fruit growing districts in the Pacific Northwest USA. Mycol. Res. 113:1301-1311.

Washington State University. 2016. Apple: Anthracnose (bull's-eye rot). 23 Mar. 2017. <http://hortsense.cahnrs.wsu. edu/Search/MainMenuWithFactSheet. aspx? CategoryId $=3$ \& PlantDefId $=59 \&$ ProblemId $=1>$.

Washington State University. 2017. Washington State University Mount Vernon station monthly data. 19 Apr. 2017. <http://weather.wsu.edu/? $\mathrm{p}=93150>$.

Zaiger, D. 1968. Diseases in cocoa production in the South Pacific. South Pacific Commission Hdbk. 2:86.

Zaiger, D. and A. Zentmyer. 1965. Phytophthora canker of cacao in the Caroline Islands. Plant Dis. Rptr. 49:566-567.

Zang, R., L. Huang, and C.L. Xiao. 2011. Species of Neofabraea responsible for anthracnose canker of apple trees in western Washington State. Phytopathology 101: S251-S255. (abstr.).

Zeller, S.M. 1926. Cankers of apple and pear in Oregon and their control. Oregon Agr. Expt. Sta. Bul. 73. 